\title{
PENGARUH PEMBELAJARAN BERBASIS MASALAH MELALUI METODE EKSPERIMEN TERHADAP KETERAMPILAN PROSES SAINS FISIKA SISWA SMA NEGERI 1 SELONG TAHUN AJARAN 2014/2015
}

\author{
Dharmawan Susanto ${ }^{1}$, Sutrio ${ }^{2}$, Wahyudi ${ }^{2}$ \\ ${ }^{1)}$ Program Studi Pendidika Fisika \\ ${ }^{2)}$ Program Studi Pendidika Fisika FKIP \\ Universitas Mataram \\ Mataram, Indonesia \\ Email: dharmawan.susanto@gmail.com
}

\begin{abstract}
This study is an experimental aims to finding out the effect of problem based learning through experimental methods on student's physics science process skills of SMA Negeri 1 Selong academic year 2014/2015. The design of this study used pretest-posttest control group design, while the sampling technique used cluster random sampling. The population of this study is students of grade X Science Program SMA Negeri 1 Selong, while the samples are the students of class X 1 (experimental group) and class X 4 (control group). The instrument of this study is the science process skills test. The result data was analyzed by t-test pooled variant two tails. Obtain values thint $=5.38$, ttable $=1.99$ at the significance level of $5 \%$. Because ttable < thint $>+$ ttable, then Ho will be rejected and Ha will be accepted which indicates that there is significant the effect of problem based learning through the experimental method on physics science process skills of students of SMA Negeri 1 Selong academic year 2014/2015.
\end{abstract}

Keywords: Science process skills, experimental methods, problem based learning.

\section{Pendahuluan}

Undang-Undang Nomor 20 Tahun 2003 tentang Sistem Pendidikan Nasional, pasal 3 menyebutkan, bahwa pendidikan nasional bertujuan untuk mengembangkan potensi peserta didik agar menjadi manusia yang beriman dan bertakwa kepada Tuhan Yang Maha Esa, berakhlak mulia, sehat, berilmu, cakap, kreatif, mandiri, dan menjadi warga negara yang demokratis serta bertanggung jawab. Dalam tujuan ini tercermin tiga aspek yang seharusnya ada dalam dalam kegiatan pembelajaran, yaitu aspek pengetahuan, keterampilan, dan sikap. Dikembangkangkannya kurikulum 2013 dalam sistem pendidikan nasional, mengupayakan aspek pengetahuan, keterampilan, dan sikap yang tercermin dalam tujuan pendidikan nasional dapat dilaksanakan dalam setiap proses pembelajaran.

Ilmu Pengetahuan Alam (IPA) atau sains berkaitan dengan cara mencari tahu tentang alam secara sistematis, sehingga IPA bukan hanya penguasaan kumpulan pengetahuan yang berupa fakta-fakta, konsep-konsep, atau prinsip-prinsip saja tetapi juga merupakan suatu proses penemuan [1]. Fisika sebagai salah satu rumpun ilmu IPA, pada hakikatnya juga terdiri atas aspek produk dan proses. Sebagai sebuah produk, fisika merupakan sekumpulan pengetahuan tentang fakta, konsep, generalisasi, prinsip, teori dan hukum fisika.
Sementara sebagai suatu proses, fisika merupakan serangkaian proses ilmiah yang dilakukan dalam menenemukan pengetahuan-pengetahuan tentang fisika [2]. Karena itu, dalam pembelajaran fisika, kegiatan pembelajaran tidak hanya ditekankan pada aspek produk saja, tetapi juga harus diimbangi dengan aspek proses.

Dalam pembelajaran sains terdapat keterampilan khusus yang harus dimiliki sebagai bentuk sains sebagai proses, yang disebut keterampilan proses sains. Keterampilan proses sains merupakan keterampilan ilmiah yang dilakukan dalam proses menemukan produk sains, termasuk fisika. Menurut Semiawan [3] keterampilan tersebut meliputi keterampilan mengobservasi, membuat hipotesis, merencanakan penelitian, mengendalikan variabel, menginterpretasi data, menyusun kesimpulan sementara, meramalkan, menerapkan, dan mengkomunikasikan. Keterampilan tersebut dapat ditumbuhkan, dilatih, bahkan dikembangkan melalui kegiatan ekperimen di sekolah.

Berdasarkan uraian di atas, keterampilan proses sains merupakan suatu tuntutan dalam proses pembelajaran fisika di kurikulum 2013, serta merupakan hakikat fisika sebagai suatu proses, sehingga dalam pembelajaran fisika, keterampilan proses ini juga harus terintegrasi dengan produk fisika. Namun, kenyataan di lapangan, pembelajaran 
fisika masih belum mengintegrasikan keterampilan proses di dalam proses pembelajarannya.

Berdasarkan hasil wawancara yang dilakukan dengan salah satu guru SMA Negeri 1 Selong, aspek sikap, pengetahuan, dan keterampilan sudah dilaksanakan dalam proses pembelajaran. Tetapi, pada aspek keterampilan, guru masih belum melakukan pelatihan dan penilaian keterampilan proses sains secara spesifik. Pengembangan keterampilan proses sains siswa masih belum tersusun secara sistematis dan dalam proses pembelajaran guru belum memfokuskan pembelajaran pada keterampilan proses sains. Hal ini terlihat dalam kegiatan eksperimen, guru belum terfokus pada aspek-aspek keterampilan proses sains siswa. Akibatnya, siswa tidak terlatih dalam menerapkan keterampilan-keterampilan ilmiah dalam proses pembelajaran, khusunya pada kegiatan eksperimen. Dari hal ini, terlihat bahwa pembelajaran fisika masih belum mengintegrasikan salah satu hakikat dari fisika itu sendiri, yaitu fisika sebagai proses dalam bentuk keterampilan proses sains.

Dalam obeservasi yang dilakukan peneliti di SMA Negeri 1 Selong, guru fisika masih terpaku pada penggunaan pendekatan saintifik yang disarankan pemerintah untuk digunakan pada kurikulum 2013. Dari hasil observasi, pendekatan saintifik yang dilakukan guru belum dikembangkan untuk melatih keterampilan proses sains siswa. Guru masih lebih fokus bagaimana siswa mampu memahami materi. Hal ini membuat pembelajaran lebih cenderung pada hasil akhir (produk) bukan pada prosesnya.

Salah satu kegiatan pembelajaran yang dianggap cocok untuk mengembangkan keterampilan proses sains adalah kegiatan pemecahan masalah. Dalam kegiatan pemecahan masalah, siswa diberi suatu permasalahan yang kemudian harus menemukan jawaban dari permasalahan itu melalui suatu proses ilmiah. Melalui proses ilmiah dalam pembelajaran berbasis masalah ini siswa dapat menumbuhkan dan mengembangkan kemampuan atau keterampilan mendasar ilmiah yang akan menuntun siswa melatih keterampilan proses sainsnya [4]. Menurut Rusman [5], masalah dapat mendorong keseriusan inquiri dan berpikir dengan cara yang yang bermakna. Pembelajaran berbasis masalah merupakan model yang sesuai untung mendorong rasa ingin tahu siswa dan melatih siswa dalam memecahkan masalah untuk mengembangkan kemampuan inquiri mereka.

Sesuai dengan permasalahan yang telah dirumuskan di atas, maka tujuan penelitian ini adalah untuk mengetahui pengaruh pembelajaran berbasis masalah (PBM) melalui metode eksperimen terhadap keterampilan proses sains fisika siswa SMA Negeri 1
Selong tahun ajaran 2014/2015. Hasil penelitian ini diharapkan bermanfaat bagi pengembangan kegiatan pembelajaran dalam mata pelajaran fisika untuk melatih keterampilan proses sains fisika serta dapat bermanfaat bagi guru, siswa, sekola serta bagi peneliti yang ingin mengambil kajian yang sama guna meningkatkan keterampilan proses sains fisika siswa.

\section{Metode Penelitian}

Jenis penelitian ini adalah penelitian eksperimen, yang merupakan metode penelitian yang digunakan untuk mencari pengaruh perlakuan tertentu terhadap yang lain dalam kondisi yang terkendalikan [6]. Penelitian ini dilaksanakan mulai bulan Oktober 2014 sampai dengan April 2015, bertempat di SMA Negeri 1 Selong. Pada penelitian ini ada tiga variabel yang menjadi fokus penelitian yaitu variabel bebas, variabel kontrol, dan variabel terikat. Variabel bebas pada penelitian ini adalah pembelajaran berbasis masalah melalui metode ekperimen, variabel terikat adalah keterampilan proses sains fisika siswa, dan variabel kontrol adalah materi, tujuan pembelajaran, instrumen, alokasi waktu dan cara penilaian. Desain penelitian menggunakan pretest-posttest control group design yang bertujuan untuk memperoleh perbedaan keterampilan proses sains fisika siswa antara kelas eksperimen dan kontrol, sehingga pada akhirnya akan mendapatkan pengaruh dari model pembelajaran yang digunakan. Secara bagan, desain penelitian ini digambarkan pada Tabel 1:

Tabel 1. Desain Penelitian Pretest-Posttest Control Group Design

\begin{tabular}{lccc} 
Kelompok & Pretest & Perlakuan & Posttest \\
\hline Eksperimen & $\mathrm{O}_{1}$ & $\mathrm{X}$ & $\mathrm{O}_{2}$ \\
Kontrol & $\mathrm{O}_{1}$ & - & $\mathrm{O}_{2}$ \\
\hline \multicolumn{4}{r}{ (Diadaptasi dari: Sugiyono, 2014) }
\end{tabular}

Keterangan:

$$
\begin{aligned}
\mathrm{O}_{1}= & \begin{array}{l}
\text { Pemberian pretest pada } \\
\text { eksperimen dan kontrol }
\end{array} \\
\mathrm{O}_{2}= & \begin{array}{l}
\text { Pemberian postest pada } \\
\text { eksperimen dan kontrol }
\end{array} \\
\mathrm{X}= & \begin{array}{l}
\text { Perlakuan berupa penggunaan pembelajaran } \\
\text { berbasis masalah dengan metode eksperimen }
\end{array} \\
\text { pada kelas eksperimen } & \\
-= & \begin{array}{l}
\text { Pembelajaran konvensional pada kelas } \\
\text { kontrol }
\end{array}
\end{aligned}
$$

Adapun teknik pengambilan sampel yang digunakan adalah cluster random sampling. Melalui cluster random sampling didapatkan dua kelas yang terpilih secara acak. Kemudian, dari dua kelas tersebut diacak kembali untuk memilih kelas eksperimen dan kelas kontrol. Sampel hasil yang didapatkan adalah kelas X Minat Sains (MS) 1 dengan jumlah 36 orang sebagai kelompok 
eksperimen dan siswa kelas X Minat Sains (MS) 4 dengan jumlah 35 orang sebagai kelompok kontrol.

Prosedur kegiatan penelitan ini dilakukan dalam tiga tahap, yaitu:

\section{Tahap Persiapan}

Pada tahap persiapan, peneliti mempersiapkan segala sesuatu yang dibutuhkan pada saat penelitian, di antaranya: (1) Melakukan observasi di sekolah terkait kegiatan belajar mengajar di SMA Negeri 1 Selong; (2) Menentukan sampel penelitian; (3) Menentukan materi pokok yang akan diajarkan dengan pembelajaran berbasis masalah melalui metode eksperimen; (4) Membuat instrumen penelitian, berupa silabus, RPP, LKS, kisi-kisi soal dan tes keterampilan proses sains; (5) Memvalidasi instrumen dengan validasi ahli; (6) Menguji coba instrumen untuk menguji validitas dan reliabilitas instrumen, serta analisis butir soal; (7) Menganalisis hasil uji coba instrumen.

\section{Tahap Pelaksanaan}

Pada tahap pelaksanaan penelitian, peneliti akan menerapkan model pembelajaran yang akan diujicobakan. Tahap ini sekaligus tahapan peneliti dalam mengambil data penelitian. Adapun langkahlangkah yang ditempuh pada saat pelaksanaan penelitian, yakni: (1) Memberikan pretest kepada kedua kelompok sampel; (2) Memberikan perlakuan kepada kelas eksperimen berupa pembelajaran berbasis masalah melalui metode eksperimen dan kelas kontrol berupa pembelajaran konvensional di sekolah; (3) Memberikan posttest kepada kedua kelompok sampel.

\section{Tahap Akhir}

Pada tahap akhir ini dilakukan analisis data penelitian, menyimpulkan data penlitian, dan membuat laporan hasil penilitian.

Teknik pengumpulan data dilakukan dengan metode tes menggunakan tes keterampilan proses sains fisika. Data keterampilan proses sains fisika merupakan data pretest sebelum diberikan perlakuan dan data posttest setelah perlakuan. Data pretest dan posttest diperoleh menggunakan instrument yang telah diujicobakan kepada 35 siswa kelas XI MS 3 yang sudah menerima materi suhu, kalor dan perpindahan kalor sebelumnya, kemudian hasil tes tersebut dianalisis dengan uji validitas, realibilitas, tingkat kesukaran dan daya beda soal. Berdasarkan hasil uji coba 55 butir soal diperoleh 23 soal yang baik digunakan untuk pretest dan posttest. Analisis validitas soal menggunakan rumus product moment dan untuk uji realibilitas soal menggunakan rumus Spearman-Brown, indeks kesukaran soal untuk tingkat kesukaran soal dan indeks diskriminasi untuk daya beda soal. Analisis data menggunakan menggunakan statistik parametrik t-test polled varians dengan kriteria uji dua pihak, yang sebelumnya telah diuji normalitas data menggunakan uji Chi Kuadrat dan homogenitas data menggunakan uji F. Sedangkan untuk mengetahui peningkatan keterampilan proses sains fisika siswa digunakan uji normalized gain $(\mathrm{g})$.

\section{Hasil Dan PEMbahasan}

Hasil penelitian berupa deskripsi data keterampilan proses sains fisika siswa dari pretest dan posttest dengan menggunakan uji homogenitas, uji normalitas dan uji hipotesis (t-test polled varians dengan kriteria uji dua pihak). Adapun data hasil pretest keterampilan proses sains fisika pada kelas eksperimen dan kelas kontrol pada materi suhu, kalor, dan perpindahan kalor dapat dilihat pada Tabel 2 berikut ini:

Tabel 2. Rekapitulasi Data Pretest pada Kedua Kelas Sampel

\begin{tabular}{|c|c|c|}
\hline \multirow[b]{2}{*}{ Komponen } & \multicolumn{2}{|c|}{ Data Pretest } \\
\hline & $\begin{array}{c}\text { Kelas } \\
\text { Eksperimen }\end{array}$ & $\begin{array}{c}\text { Kelas } \\
\text { Kontrol }\end{array}$ \\
\hline Jumlah siswa & 36 & 35 \\
\hline Nilai tertinggi & 64 & 53 \\
\hline Nilai terendah & 13 & 12 \\
\hline Rata-rata & 31,97 & 28,51 \\
\hline $\begin{array}{l}\text { Standar Deviasi } \\
\text { (SD) }\end{array}$ & 9,78 & 9,34 \\
\hline Uji Homogenitas & Homo & \\
\hline
\end{tabular}

Data hasil pretest menunjukkan bahwa nilai ratarata tes awal siswa pada kedua sampel sebesar 31,97 untuk kelas kontrol dan 28,51 untuk kelas eksperimen dengan selisih rata-rata sebesar 3,46. Pada Tabel 2, menunjukkan bahwa kelas eksperimen dan kelas kontrol homogen, yang berarti kedua kelas sampel memiliki kemampuan awal keterampilan proses sains yang sama. Berdasarkan hasil ini, pengaruh perlakuan dilakukan dengan menganalisis data posttest.

Setelah dilakukan pretest, selanjutnya kedua kelas sampel diberi perlakuan yang berbeda, kemudian dilakukan posttest. Data hasil posttest keterampilan proses sains fisika pada kelas eksperimen dan kelas kontrol pada materi suhu, kalor, dan perpindahan kalor dapat dilihat pada Tabel 3 berikut ini: 
Tabel 3. Rekapitulasi Data Posttest pada Kedua Kelas Sampel

\begin{tabular}{|c|c|c|}
\hline \multirow[b]{2}{*}{ Komponen } & \multicolumn{2}{|c|}{ Data Posttest } \\
\hline & $\begin{array}{c}\text { Kelas } \\
\text { Eksperimen }\end{array}$ & $\begin{array}{c}\text { Kelas } \\
\text { Kontrol }\end{array}$ \\
\hline Jumlah Siswa & 36 & 35 \\
\hline Nilai Tertinggi & 82 & 63 \\
\hline Nilai Terendah & 34 & 26 \\
\hline Rata-Rata & 56,47 & 43,77 \\
\hline $\begin{array}{l}\text { Standar Deviasi } \\
\text { (SD) }\end{array}$ & 10,56 & 8,56 \\
\hline Uji Normalitas & Normal & Normal \\
\hline Uji Homogenitas & \multicolumn{2}{|c|}{ Homogen } \\
\hline Uji Hipotesis & \multicolumn{2}{|c|}{$\begin{array}{c}-t_{\text {tabel }}<t_{\text {hitung }}>+t_{\text {tabel }}, \mathrm{H}_{0} \\
\text { ditolak dan } \mathrm{H}_{\mathrm{a}} \text { diterima }\end{array}$} \\
\hline
\end{tabular}

Dalam Tabel 3. di atas terlihat bahwa rata-rata nilai kelas eksperimen setelah posttest juga lebih tinggi dari pada kelas kontrol, yaitu rata-rata nilai kelas ekperimen 56,47 dan rata-rata nilai kelas kontrol 43,77, dengan selisih rata-rata yang lebih besar dari hasil pretest, yaitu 12,70. Berdasarkan hasil posttest, kelas eksperimen maupun kontrol mengalami peningkatan, yang menunjukkan terjadinya peningkatan keterampilan proses sains fisika siswa. Kelas eksperimen mengalami peningkatan nilai rata-rata sebesar 24,5 , sedangkan kelas kontrol mengalami peningkatan sebesar 15,26. Hasil di atas menunjukkan bahwa peningkatan nilai rata-rata yang dialami kelas eksperimen lebih tinggi daripada peningkatan nilai rata-rata kelas kontrol.
Selanjutnya, hasil posttest dianalisis untuk mengetahui pengaruh pembelajaran berbasis masalah (PBM) melalui metode eksperimen yang diterapkan di kelas eksperimen terhadap keterampilan proses sains fisika siswa. Berdasakan hasil uji normalitas dan homogenitas data posttest, menunjukkan data terdistribusi normal dan homogen, sehingga pengaruh PBM melalui metode eksperimen ini diuji menggunakan rumus t-test polled varians. Setelah data dianalisis menggunakan t-test polled varians diperoleh hasil $t_{\text {hitung }}=5,38$ dan $t_{\text {tabel }}=1,99$ pada derajat kebebasan 69 dengan taraf signifikansi $5 \%$. Hasil perhitungan dengan kriteria uji dua pihak menunjukkan bahwa nilai thitung lebih besar dari + ttabel dan - ttabel, yaitu $-1,99<5,38>+1,99$. Berdasarkan kriteria uji dua pihak bahwa jika -ttabel $\leq$ thitung $\leq+$ ttabel, maka H0 diterima dan $\mathrm{Ha}$ ditolak, maka hasil tes di atas menunjukkan adanya pengaruh PBM melalui metode eksperimen terhadap keterampilan proses sains fisika siswa kelas X SMA Negeri 1 Selong tahun ajaran 2014/2015.

Untuk mengetahui tingkat pengaruh perlakuan PBM melalui metode eksperimen terhadap keterampilan proses sains fisika siswa digunakan uji normalized gain $(\mathrm{g})$, yaitu suatu selisih dari hasil pretest dan posttest, dengan tujuan untuk mengetahui tingkat signifikansi peningkatan keterampilan proses sains fisika siswa setelah diberikan perlakuan. Persentase peningkatan keterampilan proses sains fisika siswa dikelompokkan ke dalam tiga kategori, yaitu rendah ( $\mathrm{g}<30 \%)$, sedang $(30 \% \leq \mathrm{g}<70 \%)$, dan tinggi $(\mathrm{g} \geq 70 \%)$. Perbandingan peningkatan keterampilan proses sains fisika siswa per aspek dan total disajikan dalam histogram pada Gambar 1 . berikut.

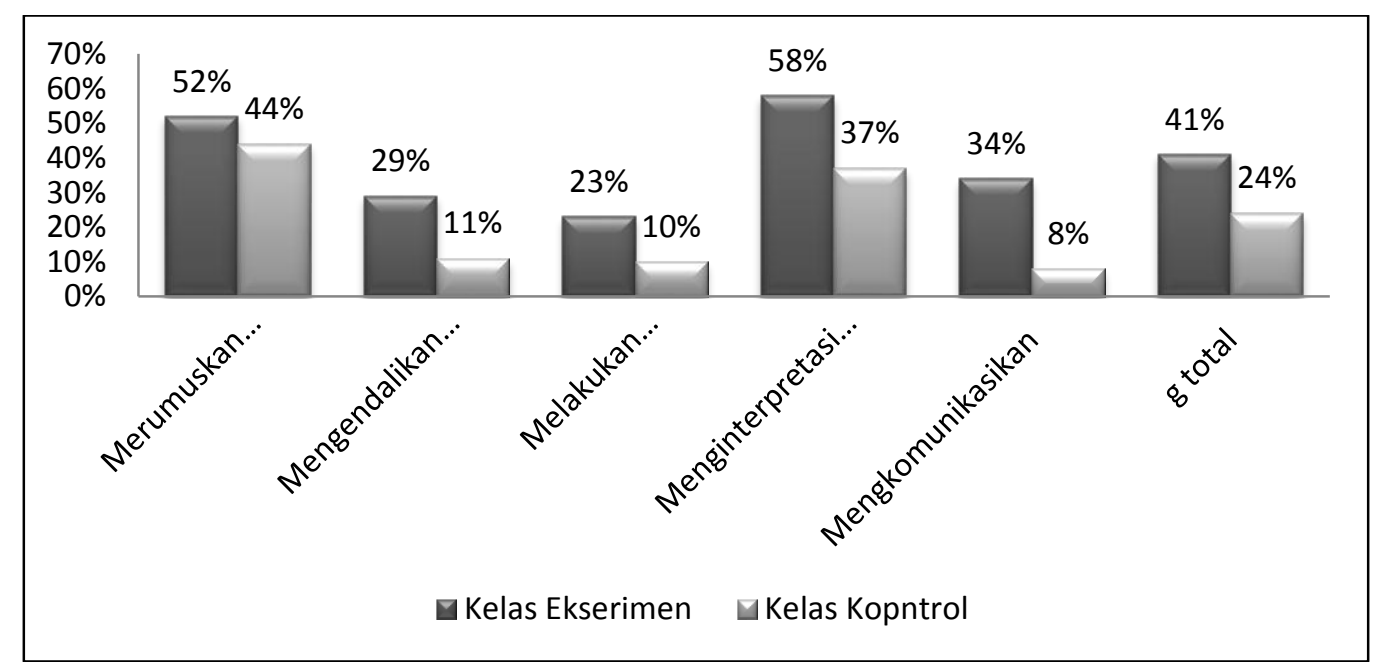

Gambar 1. Histrogram Normalized Gain Keterampilan Proses Sains Fisika Siswa 
Secara keseluruhan, kelas eksperimen mengalami peningkatan sebesar $41 \%$, yang masuk pada kategori sedang, sementara kelas kontrol mengalami peningkatas sebesar $24 \%$ yang masuk pada kategori rendah. Jika ditinjau per aspek keterampilan proses sains yang diteliti, kelas eksperimen mengalami peningkatan per aspek yang lebih tinggi dibandingkan kelas kontrol.

Data hasil pretest dan posttest, serta nilai $\mathrm{g}$ menunjukkan bahwa kelas eksperimen mengalami peningkatan keterampilan proses sains fisika yang lebih tinggi daripada kelas kontrol. Terjadinya peningkatan ini merupakan pengaruh selama pembelajaran. Selama pembelajaran materi suhu, kalor dan perpindahan kalor, siswa melakukan praktikum sebanyak 5 pertemuan. Setiap praktikum yang dilaksanakan, siswa dituntut untuk mengisi lembar kerja siswa (LKS) berbasis masalah. LKS yang digunakan menuntut proses penyelesaian masalah dalam pembelajaran berbasis masalah yang mencakup lima aspek keterampilan proses sains siswa yang sedang diteliti dan dirancang sesuai dengan praktikum yang sedang dilakukan. Dengan demikian, dalam melakukan kegiatan eksperimen siswa melalukan proses pemecahan masalah dalam pembelajaran berbasis masalah menggunakan keterampilan proses sains yang diteliti. Secara tidak langsung proses tersebut melatih keterampilan proses sains siswa menjadi lebih baik.

Fenomena di atas menunjukkan bahwa kelas eksperimen yang diberikan perlakuan berupa pembelajaran berbasis masalah melalui metode eksperimen memiliki keterampilan proses sains fisika yang lebih tinggi daripada kelas kontrol. Hal ini karena, pembelajaran berbasis masalah dengan metode eksperimen memberikan kesempatan kepada siswa untuk menyelesaikan suatu permasalahan melalui proses berpikir ilmiah yang sekaligus melatih keterampilan proses sainsnya. Menurut Rusman [5], masalah dapat mendorong keseriusan inquiri (keingintahuan). Keingintahuan siswa pada suatu masalah ini difasilitasi melalui metode eksperimen. Hasil dalam penelitian ini juga semakin menguatkan teori bahwa melalui pembelajaran berbasis masalah siswa tidak hanya memahami konsep yang relevan dengan masalah yang menjadi pusat perhatian, tetapi juga memperoleh pengalaman belajar yang berhubungan dengan keterampilan menerapkan metode ilmiah dalam pemecahan masalah dan menumbuhkan pola berpikir kritis [4]. Selain itu penggunaan metode eksperimen dalam proses pemecahan masalah dalam pembelajaran berbasis masalah memberikan kesempatan kepada siswa untuk mencari dan menemukan sendiri berbagai jawaban atas persoalan-persoalan yang dihadapinya dengan mengadakan percoabaan sendiri melalui cara berpikir yang ilmiah (scientific thinking) [7]. Keterampilan menerapkan metode ilmiah inilah yang menuntun siswa melatih keterampilan proses sainnya.

Hasil penelitian ini sekaligus menguatkan penelitian-penelitian mengenai model PBM yang telah dilakukan sebelumnya. Rusnayati dan Prima [8] dalam penelitiannya mendapatkan hasil bahwa terjadi peningkatan keterampilan keterampilan proses sains melalui penerapan pembelajaran problem based learning dengan pendekatan inkuiri. Menurut Rusnayati dan Prima [8], keterampilan proses ini dilatihkan kepada siswa pada tahap menuliskan tindakan kerja yang dilakukan dalam sintaks model pembelajaran problem based learning. Ketika proses itu dilakukan oleh siswa, maka banyak keterampilan proses yang dilatihkan kepada siswa. Hasil ini juga didukung oleh penelitian Rusmiati dan Yulianto [9] yang mendapatkan hasil bahwa penguasaan keterampilan proses sains untuk masing-masing komponen cenderung meningkat melalui penerapan model problem based instruction atau sering disebut problem based learning [10]. Menurut Rusmiati dan Yulianto [9] peningkatan ini menunjukkan bahwa keterampilan proses sains mulai tumbuh dan terbentuk seiring dengan kebiasaan yang dilakukan dan latihan secara terus menerus melalui pembelajaran problem based instruction.

\section{Penutup}

Berdasarkan rumusan masalah, hasil penelitian, dan pembahasan, maka dapat disimpulkan bahwa pada taraf signifikansi 5\% pembelajaran berbasis masalah (PBM) melalui metode eksperimen berpengaruh signifikan terhadap keterampilan proses sains fisika siswa SMA Negeri 1 Selong tahun ajaran 2014/2015.

Adapun saran yang dapat diberikan bagi guru Bagi Guru adalah pembelajaran berbasis masalah melaui metode eksperimen dapat dijadikan sebagai alternatif model pembelajaran yang dapat diterapkan untuk melatih keterampilan proses sains siswa, dengan memperhatikan beberapa hal agar proses pembelajaran dapat berjalan efektif, yaitu: (a) alokasi waktu diatur sebaik mungkin sehingga tiap tahapan pembelajaran dapat berlangsung secara maksimal, (b) alat dan bahan eksperimen disiapkan sebaik-baiknya, (c) menguji kelayakan pakai alat dan bahan yang akan digunakan dalam eksperimen, (d) melakukan kegiatan eksperimen yang tidak terlalu banyak mengingat waktu yang sedikit. Sementara bagi peneliti lain yang ingin meneliti dengan menerapkan pembelajaran pembelajaran berbasis masalah dengan metode eksperimen diharapkan menyiapkan semua 
instrumen dan perlengkapan pembelajaran dengan sebaik-baiknya untuk kelancaran penelitian.

\section{UCAPAN TERIMA KASIH}

Terima kasih penulis sampaikan kepada Bapak Drs. Sutrio, M.Si., selaku dosen pembimbing skripsi I dan Bapak Wahyudi, S.Si., M.Si., selaku dosen pembimbing skripsi II yang dengan sabar membimbing, memberikan arahan, dan nasehat sehingga penyusunan skripsi ini dapat terselesaikan dengan baik. Tak lupa pula penulis mengucapkan terima kasih kepada Bapak Dr. H. Wildan, M.Pd, selaku Dekan FKIP Universitas Mataram. Bapak Dr. Drs. Karnan, M.Si, selaku Ketua Jurusan Pendidikan MIPA. Bapak Dr. Ahmad Harjono, S.Si., M.Pd., selaku Ketua Program Studi Pendidikan Fisika, Bapak H. Sahlan, M.Pd., selaku Kepala SMA Negeri 1 Selong periode 2009-2015 dan Bapak Abdurrahim, S.Pd., selaku Kepala SMA Negeri 1 Selong periode 2015 dan seterusnya, yang telah memberikan izin untuk melaksanakan penelitian, serta semua pihak lain yang telah membantu penelitian ini.

\section{REFERENSI}

[1] Badan Standar Nasional Pendidikan (BSNP). 2006. Standar Isi Untuk Satuan Pendidikan Dasar dan Menengah. Jakarta: Pusat Kurikulum dan Perbukuan.

[2] Kementrian Pendidikan dan Kebudayaan. 2014. Ilmu Pengetahuan Alam. Jakarta: Pusat Kurikulum dan Perbukuan.

[3] Semiawan, C., Tangyong, A. F., Belen, S., Yulaelawati, dan Suseloardjo, W. 1987. Pendekatan Keterampilan Proses. Jakarta: PT Gramedia.
[4] Ngalimun. 2014. Strategi dan Model Pembelajaran. Yogyakarta: Aswaja Pressindo.

[5] Rusman. 2011. Model-Model Pembelajaran: Mengembangkan Profesionalisme Guru. Jakarta: PT Raja Grafindo Persada.

[6] Sugiyono. 2014. Penelitian Kuantitatif, Kualitatif, Study and Development. Bandung: Alfabeta.

[7] Rostiyah, N.H. 2008. Strategi Belajar Mengajar. Jakarta: PT Rineka Cipta.

[8] Rusnayati, H., dan Prima, E. C. (2011). "Penerapan Model Pembelajaran Problem Based Learning Dengan Pendekatan Inkuiri Untuk Meningkatkan Keterampilan Proses Sains dan Penguasaan Konsep Elastisitas Pada Siswa SMA". Prosiding Seminar Nasional Penelitian, Pendidikan dan Penerapan MIPA, Fakultas MIPA, Universitas Negeri Yogyakarta: 331-338.

[9] Rusmiati, A., dan Yulianto, A. (2009). "Peningkatan Keterampilan Proses Sains Dengan Menerapkan Model Problem Based-Instruction". Jurnal Pendidikan Fisika Indonesia 5: 75-78.

[10] Warsono dan Hariyanto. 2012. Pembelajaran Aktif Teori dan Asesmen. Bandung: Rosda.

\section{Bigografi Penulis}

Dhamawan Susanto, lahir di Selong, Lombok Timur, tanggal 30 Oktober 1992. Penulis menyelesaikan bangku pendidikan SD, SMP, dan SMA di Selong. Kemudian, melanjutkan studinya di Universitas Mataram pada FKIP mengambil Program Studi Pendidikan Fisika dan lulus pada tahun 2015. 